Article

\title{
The Effects of Inter-Partner Trust on Third-Country Relocation of International Joint Ventures in China
}

\author{
Yong-Sik Hwang ${ }^{1, *}$ and Kidong Kim ${ }^{2}$ \\ 1 School of Business, Sejong University, Seoul 05006, Korea \\ 2 Korea Fire Facility Association, Seoul 06694, Korea; kdkim@ekffa.or.kr \\ * Correspondence: yhwang@sejong.ac.kr; Tel.: +82-2-3408-3175
}

Received: 31 May 2018; Accepted: 4 July 2018; Published: 9 July 2018

\begin{abstract}
This study explores how inter-partner trust in international joint ventures (IJV) affects third country relocation decisions as foreign partners face an uncertain business environment in China due to wage increases and competition from local companies intensifies. As the concept of third-country relocation is relatively new compared to other international business concepts, it is crucial to find a solid framework that can explain this phenomenon. A study of 232 Korean IJVs operating in China was used to assess the relationship between inter-partner trust and third-country relocation intention. Also, we measured moderating variables that strengthen (plant performance, asset specificity, coercive pressure) and weaken (mimetic pressure and normative pressure) the negative relationship between trust and third-country relocation intention. The main effect and interaction effects were significant in showing that inter-partner trust hinders decisions on IJV's third-country relocation. In addition, the results show that trust and third-country relocation relationship interact with other moderating variables. In conclusion, our study suggests that foreign IJVs should explore various aspects such as inter-partner relationships and internal and institutional factors before making decisions on IJV relocation.
\end{abstract}

Keywords: trust; international joint venture; third-country relocation; foreign direct investment; asset specificity; institutional theory

\section{Introduction}

Many foreign manufacturing firms operating in China have been facing increased competitive pressure from recent economic transformations. Particularly, average wage increases that are expected to be $8.6 \%$ in 2015, two-thirds higher than in Vietnam [1]. In addition to wage increase pressures, the Chinese government has transformed the economic structure from labor intensiveness to new technology-oriented businesses such as 3-D printing and high-end machine development.

Foreign manufacturing firms, which are usually in labor-intensive sectors-such as toys, clothing, and other light manufacturing industries-perceive the transformation as institutional pressures that may cause them to suspend operations in China. The Boston Consulting Group recently surveyed 106 U.S. manufacturing firms operating in China and found that $37 \%$ intend to relocate their manufacturing bases to nations that have less institutional pressure [2]. Also, global corporations-including GE, Whirlpool, Toshiba, Foxconn, and Canon-have announced that they will relocate some of their Chinese manufacturing plants to other foreign countries or to their home counties.

China is clearly experiencing relocation disturbances in its manufacturing sector. Global manufacturers operating in China know that relocations are important strategic options involving external uncertainties. Manufacturers considering relocation must evaluate how they are affected by several risk factors [3] such as new governmental/political, macroeconomic, managerial, 
and competitive environments, cost escalation, hidden costs, future contract negotiation issues, loss of core competencies, and opportunism by partner firms.

Recently, however, some foreign manufacturing firms have begun relocating elsewhere, mostly to the Southeast Asian (ASEAN) region. For instance, in 2001, China had $40 \%$ of the world volume in the manufacturing of shoes, but by 2010, Vietnam had seized $37 \%$ of the world volume, and China had dropped to $34 \%$ [4]. The migration to phenomenon is mainly related to increased wages in the Chinese workforce. In 2012, 25 provinces in China increased their average minimum wages by $20.2 \%$. As of 2015 , those wages are expected to increase an average of $13 \%$ yearly [5]. Specifically, the base wages for entry-level factory workers are approximately $71 \%$ higher than they were five years ago.

The wage increases have widened the wage gap between workers in China and workers in other ASEAN regions. For example, in 2013, China's labor cost was $224.8 \%$ higher than it was in Cambodia, 182\% higher than that of Bangladesh, and 195.3\% higher than that of Vietnam [5]. Moreover, the appreciation of Yuan currency, rising raw material prices, and strict environmental and labor laws add to the difficulty of making profits in China. Simultaneously, ASEAN countries are aggressively promoting investment in manufacturing sectors. One incentive they offer is the exemption of import tariffs on previously operated equipment from China for future manufacturing plants.

As a manufacturing firm's relocation strategy is relatively new terminology within the field of international business, academic research on relocation is mainly focusing 'reshoring' topic [6-8]. Reshoring is defined as the relocation of value creation activities from offshore locations to home country locations [6-8]. Specifically, reshoring is defined as the reverse decision of a previous decision to offshore. However, we found a research gap that reshoring does not represent relocation of manufacturing firms since some foreign manufacturers cannot reshore to their home country for some reasons. For Korean manufacturing companies operating in China, they are reluctant to reshore to their home country, South Korea, mainly because of Korea's high labor costs [9]. Unfortunately, intense competition with local Chinese competitors and other business environmental changes drove many to relocate their facilities to Korea or to third countries such as ASEAN nations [9]. Instead, Korean manufacturers opt for more practical decision to relocate to third countries such as ASEAN nations. In this study, we call this type of relocation as 'third-country relocation' and third-country relocation is defined as the relocation of value creation activities from offshore locations to other offshore locations. We find that relocation research is more focused on reshoring issue than third-country relocation. Therefore, in this research, we will further explore the topic of third-country relocation and this concept will be explained in detail following section.

A reshoring paper by Fratocchi et al. [6] summarizes the motivations for manufacturing reshoring by addressing why the phenomenon happens in the manufacturing sector. Specifically, the authors propose that manufacturing firms mainly consider reshoring for cost efficiency. They also note that in addition to the minimization of overall costs, there might be other aspects related to manufacturing reshoring. A study by Foerstl et al. [7] also proposes that manufacturing firms may not only have cost factors in mind. In addition to cost factors, researchers may consider other internal and external factors that shape decisions on reshoring. In this research, we will further explore additional motivations for third-country relocation other than cost factors.

Also, as many foreign manufacturers enter China in international joint ventures (IJV), scholars in the IJV area have been investigating the role of 'inter-partner trust' to explain how foreign manufacturers manage the relational aspect with local Chinese partners [10-12]. Particularly, most research on inter-partner trust in IJV has focused on performance aspects in China rather than relocation decision making. In this study, we also examine how inter-partner trust has different effects on third-country relocation decisions depending on the level of the internal aspects of a manufacturing firm and institutional pressures perceived by foreign manufacturers. We assume that the internal dynamics of the firms in the decision-making process are significant and that they lead to a relocation decision. Firms are path-dependent and may make relocation decisions based on their internal situation, such as asset-specific resources and current firm performance. Before making decisions on 
third-country relocation, manufacturing firms need to consider how much they have invested in the current operating location and how they have been performing over the years.

In addition, manufacturing operations in China are heavily influenced by formal and informal institutional changes [13] involving macroeconomic government policies and regulations. Previous research applied institutional theory $[14,15]$ to explain how multinational firms manage institutional changes. The institutional perspective is appropriate for exploring how isomorphic pressure coming from institutional changes shapes firms' decision making [16,17] such as third-country relocation decisions. Although trust helps foreign manufacturers to cope with external uncertainties, we assume that this relationship can be moderated depending on the degree of institutional pressure surrounding the foreign manufacturers.

Furthermore, our research explores the relocation phenomenon from an Asian perspective. Earlier relocation (reshoring) research used either U.S. or European manufacturing firms' samples [6-8]. Thus, the topic of relocation should not be limited to only Western manufacturers, because Asian manufacturers from South Korea and Japan also entered China throughout the 1990s and 2000s. As of 2016, there are 1967 Korean manufacturers operating in China [18].

In the next section, we introduce the relevant theory and hypotheses. In the third section, we introduce the data and methodology used, followed by analytical results and further elaboration of empirical results. The last section concludes with discussions of study results, significance, and limitations of the research, and further research issues.

\section{Literature Review and Hypotheses Development}

\subsection{Third-Country Relocation}

We categorize firm relocation strategies using a four-field matrix (Figure 1) including domestic relocation, internationalization, reshoring, and third-country relocation. Domestic relocation began in the 1950s when European and American firms started searching for new locations [19]. Theories have taken three perspectives to explain reasons for domestic relocations: neoclassical, behavioral, and institutional location [19]. The neo-classical location theory explains that when costs increase and when current locations are no longer inside profitability spatial margins, firms relocate to maximize profit. The behavioral location theory explains that internal factors such as growth and performance [20] affect relocation decisions. The institutional location theory explains that relocation strategies depend on ongoing social, institutional, and governmental interactions [19].

\section{Current Location}

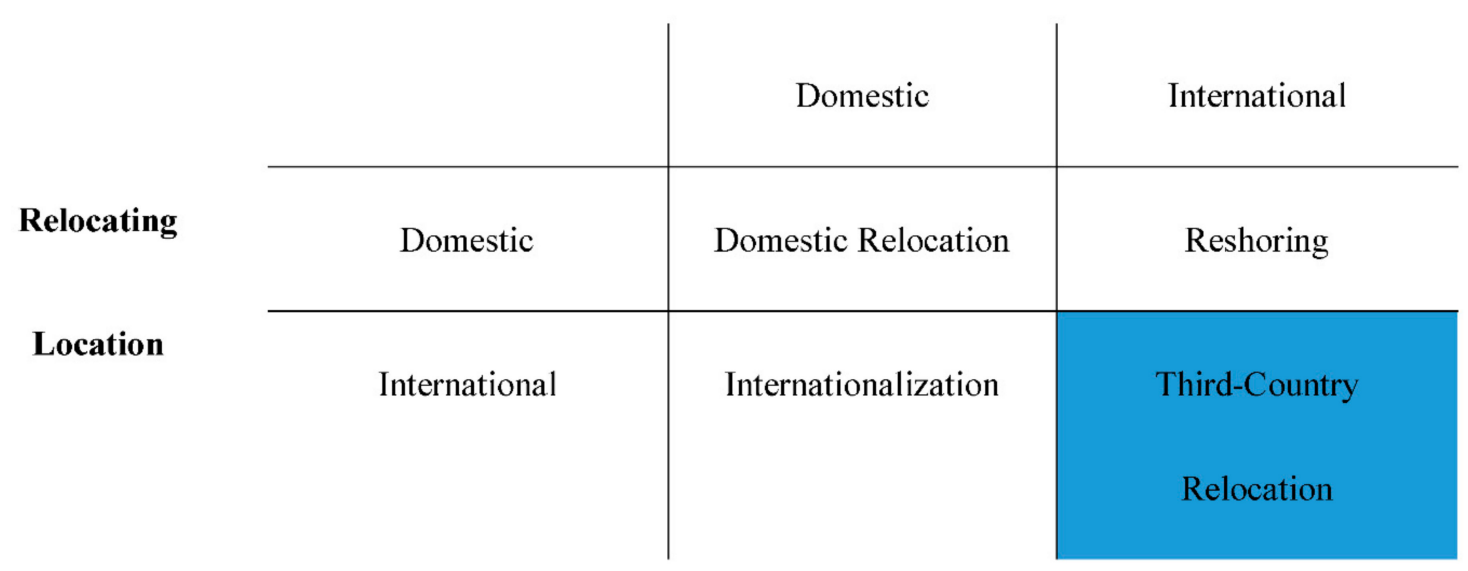

Figure 1. Four types of firm relocation strategy. 
As many firms started relocating their manufacturing bases from domestic to international locations (internationalization), international business researchers began to study internationalization theoretically and empirically [21,22]. They suggested powerful frameworks such as "internationalization theory" and the "eclectic paradigm of ownership" to explain why firms relocate from domestic to international bases. In the early stage of internationalization, labor-intensive activities were most likely to be relocated overseas, whereas capital-intensive activities stayed in their domestic locations.

Internationalization introduced new problems such as growing transaction and coordination costs, instability of government policy, opportunistic behavior of local partners, cultural differences, and difficulties in supply and material handling. Consequently, some internationalized firms began considering second relocations, either back to their home country (reshoring) or to another international location (third-country relocation). If they choose reshoring, they relocate production activities from the international location to the domestic location [23].

Although researchers have studied domestic relocations, internationalizations, and reshoring for several decades, the literature has failed to consider relocation activities in firms that move from one foreign location to another (shaded area in Figure 1), as is recently occurring in China. We call this type of relocation activity third-country relocation.

Previous literature on relocation describes the factors that drive foreign manufacturing firms to relocate to other countries. The first driver of relocation decision is explained well by transaction cost economics (TCE), which states that individual firms tend to move away from a higher cost location to a lower cost location [24]. In respect to third-country relocation decisions, manufacturing firms may decide to relocate to a third country if the firms find that locating production activities in the third country is cheaper than retaining the current facility. With respect to trust, opportunism from local partner firms plays a major role in relocation. Opportunism describes when transaction partners act with self-interest [24]. For instance, $21.9 \%$ of Japanese manufacturing firms operating overseas perceive that technology leakage is a serious problem [25]. If a certain technology is critical for a foreign manufacturing firm's competitive advantage, they must pay extra attention to intellectual property protection. Eventually, the opportunism of local partner firms may increase transaction costs with higher coordination and control costs, resulting in relocation alternatives [26].

The second driving factor of relocation is the financial performance of offshoring manufacturing firms. Financially under-performing foreign manufacturers tend to have a shorter duration of offshoring than high-performing ones [27]. Dunning's eclectic theory [28] proposes three determinants of international production by multinational enterprises: that ownership advantages, location advantages, and internalization advantages are the main drivers for foreign direct investment (FDI). If foreign manufacturers are not able to sustain any of these advantages in their foreign operation, they may face strategic imperatives for relocation [29].

The last driving factor of relocation is the environmental uncertainty foreign manufacturing firms are exposed to with potential disturbances and volatility in the marketplace [30]. Specifically, macroeconomic changes-such as economic growth rate, resource shortages, and volatility in exchange rates-stimulate more uncertainty in the international business environment [31]. Since foreign manufacturing firms are operating with the liability of foreignness, they are prone to be vulnerable to changes in institutional policy and regulations such as subsidies, labor laws, tax structures, and political stability [31].

\subsection{Trust, Behavioral Theory, and Institutional Isomorphism}

First, according to Rotter [32], trust is "an expectancy held by an individual or a group that the word, verbal promise, or written statement of another individual or group can be relied on (p. 444)." In the IJV context, Parkhe [33] specified that inter-partner trust leads to the stability and performance of IJVs. Although it is known that trust is a critical factor in the performance of IJVs, it may have different outcomes depending on external environmental factors [34]. They suggest that the role of 
institutional support for trust influences IJV performance, and therefore the effect of inter-partner trust on IJV performance is not in a direct relationship all the time.

Second, behavioral theory $[35,36]$ is related to the internal factors of manufacturing firms. Current performance such as lead time, inventory control, and quality management are the determinants of reshoring decisions. Also, reshoring decisions can be determined based on asset-specific investments that cannot be capitalized if firms decide to relocate to their home country. A reshoring decision is likely to be determined depending on how much the foreign manufacturer has invested overseas.

Third, institutional theory in management focuses on how the systems surrounding firms shape their behaviors and decisions [37]. The theory explains that formal regulations and informal constraints such as norms and codes of conduct constrain and control human interactions [38]. Institutional theory fundamentally argues that firms choose acceptable and legitimate behavior within their operational boundaries. In other words, coercive, imitative, and normative pressures coming from institutional environments affect their decisions [39]. When firms within the same institutional environment come to resemble one another, the tendency is called 'institutional isomorphism' [37]. That is, firms align with other firms to achieve legitimacy and social acceptance for long-term sustained operations.

Institutional isomorphism is subject to three forces: (1) coercive pressure from political or governmental influence, (2) mimetic pressure from responses to uncertainty, and (3) normative pressure related to the professional arena [39]. The three isomorphic pressures cause firms to strive for legitimacy within the institutional environment.

\subsection{Inter-Partner Trust and Third-Country Relocation}

Inter-partner trust may help to achieve the goals of both sides of IJV as contractual and bureaucratic mechanisms may not be useful in controlling the opportunistic behavior of the other party [40]. The presence of trust between partners accelerates closer interaction and information sharing activities, enabling the achievement of "value creating" performance [41]. In other words, inter-partner trust helps to build social capital in the long run, which leads to value in the IJV relationship [42]. Baird et al. [43], found that trust was ranked first for successful Chinese and U.S. joint ventures. $\mathrm{Li}$ et al. [44] also emphasized that in uncertain environments, the development of trust between IJV partners may enhance IJV performance. This is mainly because inter-partner trust facilitates partners to readjust to a changing environment by interacting and cooperating with partner firms [45]. When an IJV is confronted with an uncertain external environment, a partner firm with a trust relationship might explain the situation and show commitment to overcoming it. Inter-partner trust expedites mutual understanding and allows IJVs to deal with doubtful and uncertain external environments. Hence, in line with earlier research, we suggest that inter-partner trust is negatively related to a foreign manufacturing firm's relocation intention.

Hypothesis 1 (H1). Ceteris paribus, inter-partner trust is negatively related to the IJV foreign partner's relocation intention to the third country.

\subsection{Behavioral Theory}

\subsubsection{Plant Performance}

Behavioral theory on plant relocation argues that a firm has a rational system that adapts and responds to organizational performance [35]. The behavioral perspective defines firms as boundedly rational decision makers that are responsive to performance feedback [36]. When firms find their plant performance declining, they may question their current strategies and consider future redirections. Relocation decisions involve significant organizational change, complexity, and ambiguity, so when plants are performing well, instead of considering reshoring, they will focus on continuing their current 
successful operations and trying to cooperate more with the local IJV partner. Well-performing IJVs generally have cost advantages in their current operations and are protected from new entrants by entry barriers.

Also, well-performing IJVs may likely have intangible assets, such as technological capabilities [28]. According to resource-based theory, the possession of scarce and valuable resources is a source of competitive advantage [46]. Manufacturers that possess technological capabilities have expertise in mobilizing technical resources through routines and practices that allow new products or innovations [47].

IJVs that have strong manufacturing capabilities perceive that they have sustainable competitive advantages for the present and future. By exploiting their current manufacturing capabilities, they can expect sustained competitive advantages in overseas markets [48]. In volatile external environments in particular, competitive IJVs are assured of continued superior financial performance [49].

Previous research also shows that firm performance affects organizational transformation [36,50]. Well-performing firms are less likely to be sensitive to external changes and less likely to search for better solutions [35]. However, when IJVs face performance pressures, decision makers consider reconfiguring firm operations. In sum, we assume that IJVs with good performance are less likely to consider relocation, which strengthens the negative relationship between inter-partner trust and relocation intention.

Hypothesis 2 (H2). The performance of IJVs moderates the negative relationship between inter-partner trust and the foreign partner's third-country relocation intention. A high-performing IJV is less likely to relocate to another country.

\subsubsection{Asset Specificity}

Certain firms have specific assets that allow them to reduce inefficient haggling and negotiations that lead to transaction costs and opportunism. Asset specificity can be relational and intangible assets that evolve over time. To achieve high asset specificity, firms must either internalize their assets [51] or find business partners that have built long-term trust [52]. The specificity of assets comes from three sources: site specificity, the specificity of physical assets such as components or equipment, and the specificity of human resources [53].

In the Chinese IJV system, foreign manufacturers with asset specificity are likely to benefit from and exploit strategic opportunities that the Chinese government provides-such as tax incentives, subsidies, and assistance in building "guanxi" with local suppliers and buyers [40]. IJVs that have accumulated asset-specific trust in and commitment to the Chinese market would find it difficult to relinquish those resources for relocation because in the long run, IJVs need to exploit proprietary knowledge in both technology and management [54]. When foreign manufacturers invest overseas, they assume that they will gain the most out of the assets contributed [53]. As the firms are deeply involved in more asset-specific capital, they may make more efforts to achieve efficiency gains [55]. Following this argument, if the foreign IJV partner finds that their firm has high asset specificity, they are less likely to have the intention to relocate their manufacturing base. Specific assets will then be exit barriers for relocation decisions and strengthen the negative relationship between inter-partner trust and relocation intention.

Hypothesis 3 (H3). The asset specificity of IJVs moderates the negative relationship between inter-partner trust and the IJV foreign partner's third-country relocation intention. High asset-specific IJVs are less likely to relocate to other countries. 


\subsection{Institutional Theory}

\subsubsection{Coercive Pressure}

When governments place mandates or restrictions on organizations, manufacturing firms may perceive coercive pressure [39]. In response, they may decide to change their organizational structure and practices to conform to government mandates. Coercive pressure and the decision making of manufacturing firms will be more prominently related in emerging economies such as China's where the economic structure depends heavily on the government's macroeconomic policies. Government policies exert considerable control over foreign manufacturing firms and choices to relocate. For example, the Chinese government mandates that foreign manufacturers who exit but have less than 10 years of operating history in China must return all the tax incentives they received, must negotiate with labor representatives to provide compensation for displaced workers, must liquidate their remaining assets for local Chinese partners at below market value, and must pay off any loans from Chinese financial institutions. Foreign manufacturing firms may perceive these FDI policies to be coercive pressures and exit barriers. In summary, foreign manufacturers that want to relocate to their home countries must go through complex procedures and face significant transaction costs. As a result, they are likely to enforce the negative relationship between inter-partner trust and relocation intention.

Hypothesis 4 (H4). Perceived coercive pressure moderates the negative relationship between inter-partner trust and the IJV foreign partner's third-country relocation intention. High coercive pressure reduces the likelihood of third-country relocation.

\subsubsection{Mimetic Pressure}

With respect to mimetic pressure, when firms face uncertain environments, they tend to imitate the decisions of other firms [39]; that is, they experience mimetic pressure to adopt similar intentions and implement analogous decisions. In other words, the firms may consider that they will better fit the legitimate social structure by imitating other successful organizations. The literature on internationalization indicates that firms tend to imitate competitors' international expansion strategies [56], entry modes [57], and operational strategies in foreign markets [58]. As internationalization involves high levels of risk, so firms are likely to minimize risks by imitating their competitors' decisions. Similarly, foreign manufacturing firms may observe how other foreign IJV competitors react to China's recent transformations and shape their relocation decision according to the decisions of other firms. For instance, many successful global corporations including GE, Whirlpool, Toshiba, Foxconn, and Canon recently announced plans to relocate their Chinese manufacturing plants to their home country. Also, recent FDI inflow trends clearly show that ASEAN nations are attracting more FDI. In 2001, China had $40 \%$ of the world volume in sneaker manufacturing, but by 2010, Vietnam had captured 37\% of the world volume, and China dropped to 34\% [4]. The recent increase in FDI inflow to ASEAN nations should shape mimetic pressure so that the foreign IJV partner in China will eventually form relocation intentions. The more prevalent relocation practices are in an industry and the more successful relocation practices turn out to be, the more likely relocation decisions are legitimate and reliable. Conversely, the uncertainty of relocation activity may lead to fear of failure, in which case the foreign IJV partners in China are more likely to avoid relocation if peer firms show a tendency to neglect a reshoring decision. Hence, mimetic pressure coming from other foreign competitors in China are likely to weaken the negative relationship between inter-partner trust and IJV foreign partner's relocation intention.

Hypothesis 5 (H5). Perceived mimetic pressure moderates the negative relationship between inter-partner trust and the IJV foreign partner's third-country relocation intention. Low mimetic pressure reduces the likelihood of third-country relocation. 


\subsubsection{Normative Pressure and Third-Country Relocation}

Normative pressure is the expectation to follow the social expectations of the host country when foreign manufacturers conduct overseas IJVs. All host nations have normative systems of shared norms, culture, beliefs, and values [53]. Foreign manufacturers may feel that the host government is pressuring them to conform to the local normative system. If the hosts fail, they risk liability that brings loss of social image, deteriorated brand value, and high transaction costs for building business networks. Foreign firms may perceive normative pressure from the local government, business networks, and customers to varying degrees depending on whether the normative system embraces or resists foreign firms. With respect to relocation context, if foreign manufacturing firms perceive high normative pressure, they are likely to consider relocation. If the foreign manufacturer is embedded in the normative system of the host nation, relocation intentions are less likely. For instance, a normative system consists of inter-organizational channels such as firm-supplier networks, firm-buyer networks, and other relational channels within the domestic industry. If foreign manufacturing firms have weak relational norms, they may perceive pressure to conform to shared norms. The failure to adopt a practice of direct or indirect relationships with local counterparts may lead foreign manufacturing firms to consider a reshoring decision. Even when a foreign IJV partner has a trust relationship with a local IJV partner, when they perceive that the competitive advantage of the IJV has eroded due to normative pressure coming from local competition and unfamiliar business practices, the negative relationship between inter-partner trust and relocation intention will be mitigated. Based on the above conclusions, we propose the following hypothesis:

Hypothesis 6 (H6). Perceived normative pressure moderates the negative relationship between inter-partner trust and the IJV foreign partner's relocation intention. Low normative pressure reduces the likelihood of third-country relocation.

In summary, Figure 2 describes the conceptual framework of this study. The negative relationship between inter-partner trust and third-country relocation (H1) is positively moderated by plant performance (H2), asset specificity (H3), and coercive pressure (H4); and negatively moderated by mimetic pressure (H5) and normative pressure (H6). This research model was analyzed with empirical data.

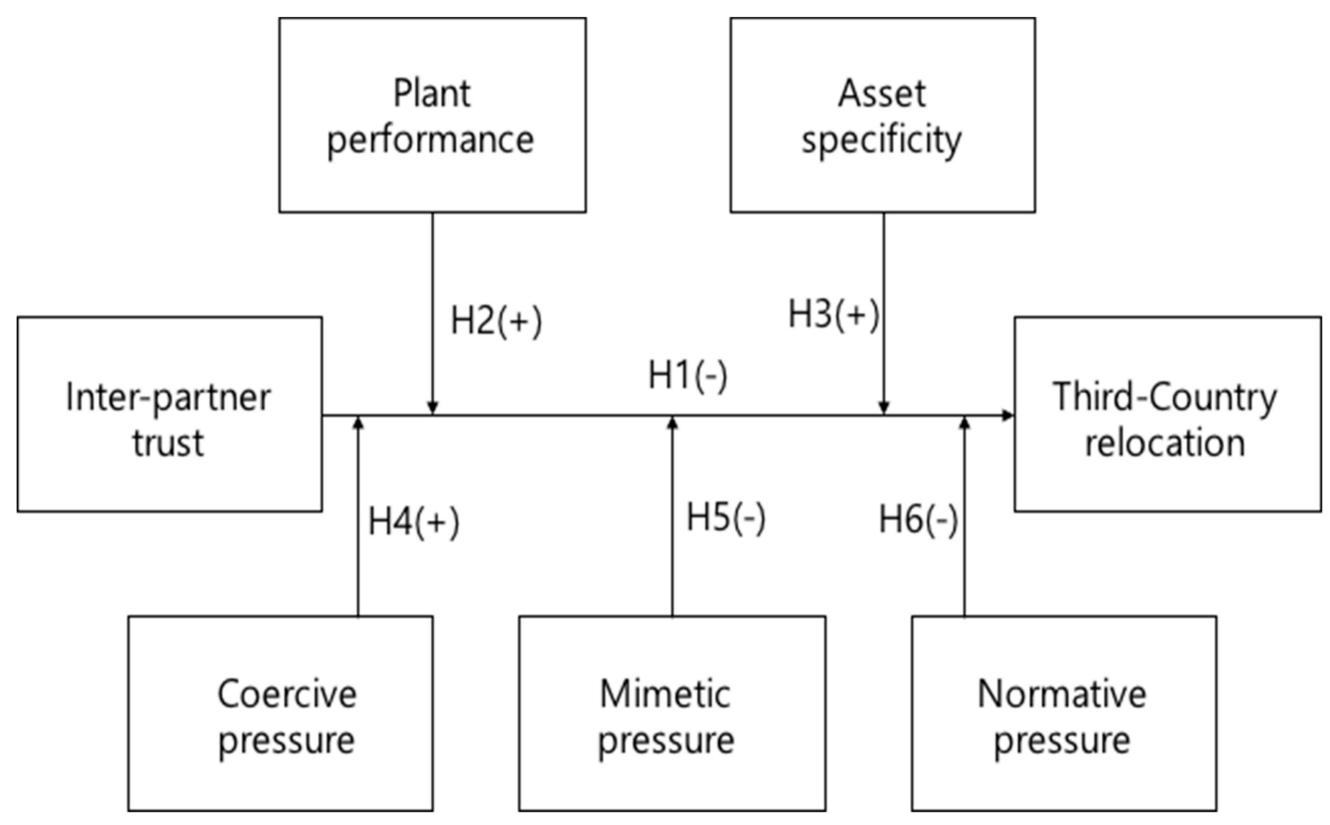

Figure 2. Conceptual framework. 


\section{Methods}

\subsection{Research Setting}

The Chinese market is a rich context for analyzing the third-country relocation phenomenon in terms of an Asian perspective as many Asian manufacturing firms are located in China. We collected data from South Korean manufacturers operating in China, which is geographically close to South Korea. Since the early 1990s, after South Korea and China officially formed a diplomatic relationship, many Korean manufacturing firms have relocated to China for its low-cost workforce [9].

To ensure the reliability and validity of the survey design, we initially conducted in-depth interviews with factory managers from nine manufacturing firms who have roles in strategic decision making and operations in China. They explained the factors that may influence decision making for third-country relocation. The in-depth interviews allowed us to cross-check the relevance of measures on the relocation decision process and other variables before survey questionnaires were designed.

The data for this research were collected from Korean manufacturing firms operating in China. In order to fully gain an understanding of the trust and third-country relocation decision-making process, we selected Korean manufacturing firms that have IJV ownership in China. If Korean firms did not have an equity share with local Chinese partners, we would not be able to measure the trust relationship between them. We first identified 351 manufacturers by using a database provided by the Korea Trade-Investment Promotion Agency [18]. The database contains detailed information, including company contacts, ownership status, and major product lines. We double-checked the current operation status of each manufacturing firm by either visiting their corporate website or contacting them by phone to confirm the accuracy of the database. Out of the $351 \mathrm{IJV}$ firms listed, 329 were identified to have an operating status.

The survey took place between January and March of 2017, and questionnaires were mailed to the managers in charge of their respective plant operations in China. To increase the response rate, research assistants called and emailed the survey participants reminding them to complete the survey. Of the 329 questionnaires sent out, 232 were completed (a 70.5\% response rate), and all were suitable for statistical analysis. The responding firms were from diverse industries such as textiles, clothing, leather, chemical materials, rubber products, plastic products, metal products, general machinery, electrical machinery, and electronics. We categorized each industry into light $(43.1 \%)$, medium $(36.2 \%)$, and heavy $(20.7 \%)$ industry according to Chinese industry code system. Table 1 describes the breakdown of industry sample.

Most of the respondents, $93 \%$, identified themselves as senior managers who make major decisions about firm operations; $7 \%$ were at managerial levels and had major strategic roles in firm operations; $82 \%$ had been employed for more than five years; and all had college degrees or above. Also, $83 \%$ of the companies have parent companies in Korea and $17 \%$ of the companies started in China by Korean nationals. We consider Korean startups in China as the second location since these companies are registered as foreign companies in China and they settled down in China for the same reason (low cost labor) of relocation from Korea. 28\% have fewer than 100 employees in China, $40 \%$ have 100-200 employees, and 32\% have more than 200 employees.

We tested the responses for nonresponse bias with Kolmogorov-Smirnov tests by using three parameters (industry classification, total capital investment, and number of employees). The results showed no significant differences between respondents and non-respondents. Also, to check the common method bias problem, we conducted Harman's one factor test [59]. The results showed that neither a single factor nor a general factor could account for the majority of the covariance. In addition, we sent the same questionnaire to top executives of the parent companies in South Korea from 20 randomly selected sample firms whose factory managers in China had responded to our survey earlier. From this process we collected 12 responses, but there were no significant differences between two respondents from the same firm. The results indicate that common method bias was not a major issue in this research. 
Table 1. Breakdown of IJVs by industry size

\begin{tabular}{|c|c|c|c|}
\hline Industry Type & Items & Number of IJVs & Industry Type Percentage \\
\hline \multirow[t]{8}{*}{ Heavy } & Chemicals & 8 & $20.7 \%$ \\
\hline & Basic metal & 5 & \\
\hline & Fabricated metal & 7 & \\
\hline & General machinery & 10 & \\
\hline & Electrical machinery & 6 & \\
\hline & Electronics & & \\
\hline & Chemical materials & 7 & \\
\hline & Transportation equipment & 5 & \\
\hline \multirow[t]{7}{*}{ Medium } & Rubber & 21 & $36.2 \%$ \\
\hline & Plastic & 29 & \\
\hline & Food & 8 & \\
\hline & Beverage & 5 & \\
\hline & Furniture and fixtures & 11 & \\
\hline & Paper & 6 & \\
\hline & Optical engineering & 4 & \\
\hline \multirow[t]{6}{*}{ Light } & Textiles & 38 & $43.1 \%$ \\
\hline & Clothing & 32 & \\
\hline & Leather & 8 & \\
\hline & Footwear & 9 & \\
\hline & Jewelry & 4 & \\
\hline & Toy & 9 & \\
\hline Total & & 232 & $100 \%$ \\
\hline
\end{tabular}

\subsection{Measures}

For the dependent variable, decision makers indicated their intentions to relocate their manufacturing facility to the third-country in three years on a five-point Likert-type scale ( 1 = very unlikely to $5=$ very likely). We adopted and modified the relocation measurement from Sharif and Huang's [60] study on the decision of Hong Kong firms to relocate from China to other regions.

For the inter-partner trust variable (alpha $=0.85)$, we adopted the measurement from the research of Morgan and Hunt [61]. Foreign IJV partners were asked to evaluate whether the local IJV partner (i) can be counted on to do what is right, (ii) is always faithful, (iii) is someone we have great confidence in and (iv) has high integrity on a five-point Likert scale ( $1=$ very unlikely to $5=$ very likely).

For plant performance measures (alpha $=0.79$ ), we adopted four measurements that are widely used in operation management [62]: lead time, inventory, quality, and set-up time. For each of the items, firms were asked to evaluate the performance of the above measures on a five-point Likert scale with end points of 1 (not satisfied at all) to 5 (very satisfied).

To measure the asset specificity variable (alpha $=0.86$ ), we used three items [51]. We asked respondents to evaluate the current manufacturing operation in China, which requires significant financial and relational investments. The participants rated their perceptions according to a Likert scale with end points of 1 (low extent) to 5 (high extent).

For the coercive pressure variable (alpha $=0.93)$, respondents were asked to indicate perceived pressure from the host country's central government, local government, and financial institutions on reshoring, respectively $[63,64]$. The respondents rated this according to a Likert scale with end points of 1 (low extent) to 5 (high extent).

Mimetic pressure [65] was measured with three items (alpha $=0.85$ ): competitors are increasing reshoring decisions; competitors have benefitted from reshoring; and, the industry favorably recognizes reshoring. The participants indicated their responses according to a five-point Likert scale with end points of 1 (low extent) to 5 (high extent). 
Following Yiu and Makino [58], we used three items to measure normative pressure (alpha $=0.92$ ) on managers' perceptions regarding whether foreign manufacturers are treated unequally compared with local manufacturers, whether the host country prefers local businesses over foreign businesses, and whether the host country has professional standards that make it difficult for foreign manufacturers to operate there. The participants answered according to a five-point Likert scale with end points of 1 (low extent) to 5 (high extent).

Control variables that may affect relocation decision were IJV age, IJV size, and industry. This paper assumes that larger IJVs that have operated for a long time are less likely to relocate. Institutional theory concludes that older firms are more embedded in trust-based networks [66]. Also, smaller manufacturers may have less invested capital to divest and more flexibility to relocate [67]. The number of years an IJV has operated in China was used as a proxy for firm age. The number of employees and the value of tangible assets (property, plant, and equipment) were proxy variables for measuring IJV size [68]. Lastly, industries were categorized as heavy, medium, and light by adopting the Chinese industry code system (Table 1). Medium industry was used as the reference group and two dummy variables were used to represent heavy and light industry.

\section{Results}

Table 2 shows the summary statistics and correlations associated with variables. To avoid multicollinearity problems, we further tested the variance inflation factor (VIF), which showed that multicollinearity was not a concern since all the VIF scores were significantly less than 5 [69], and that regression analysis could be executed. Thus, the following examinations identified the factors that contribute to reshoring decisions.

Table 3 shows the results of ordinary least squares regression for this research. In Model 1 , the control model, IJV age $(\beta=-0.103, p<0.001)$ and size of IJV assets $(\beta=-0.006, p<0.05)$ were negatively related to relocation intentions. We assume that older and bigger IJVs would be less likely to consider a relocation decision, which requires major changes in current operations in China.

After testing the control variables in Model 1, we analyzed the main variables in Model 2. The results show that inter-partner trust is negatively related to relocation intention. The coefficient for trust of the local partner is negative and significant $(\beta=-0.523, p<0.001)$, supporting Hypothesis 1 .

The results of Model 3 show that the incremental variance accounted for by the interactions between behavioral theory variables (plant performance and asset specificity) and trust on host country partner is significant $\left(\Delta R^{2}=0.052, p<0.01\right)$. Hypothesis 2 and Hypothesis 3 predict that a negative relationship between trust and relocation intention will be stronger when the IJV's performance is high and the IJV has high asset specificity. The coefficient of the interaction of partner trust with plant performance is significant $(\beta=0.025, p<0.05)$ and supports Hypothesis 2 . Hypothesis 3 is also supported as we find a significant $(\beta=0.210, p<0.01)$ interaction between partner trust and asset specificity. To further analyze the implications of the regression results, we plotted the relationship of partner trust and relocation intention over the observed range of partner trust with different levels of plant performance (Figure 2). Figure 3 reveals that the magnitude of the slope of relocation intention regressed on partner trust is approximately twice as large for low performance as that for high performance. Also, Figure 4 shows a similar plot with asset specificity. Figure 4 shows that the slope for low asset specificity is almost three times as large as that for high asset specificity. Overall, these results imply that the negative trust-relocation relationship strengthens at high levels of two behavioral variables (plant performance and asset specificity). 
Table 2. Descriptive Statistics and Correlation Matrix

\begin{tabular}{|c|c|c|c|c|c|c|c|c|c|c|c|c|c|}
\hline Variable & Mean & SD & 1 & 2 & 3 & 4 & 5 & 6 & 7 & 8 & 9 & 10 & 11 \\
\hline 1. Relocation & 3.256 & 0.881 & & & & & & & & & & & \\
\hline 2. IJV Age & 9.272 & 7.332 & $-0.338^{* * * *}$ & & & & & & & & & & \\
\hline 3. Asset & 4524.450 & 1.661 & $-0.232 *$ & 0.075 & & & & & & & & & \\
\hline 4. Employees & 118.730 & 92.200 & -0.030 & 0.063 & 0.041 & & & & & & & & \\
\hline 5. Light Ind. & 0.354 & 0.490 & 0.031 & 0.091 & $0.242 * *$ & 0.013 & & & & & & & \\
\hline 6. Heavy Ind. & 0.371 & 0.500 & 0.002 & 0.036 & $0.542 * *$ & $0.226^{* *}$ & 0.024 & & & & & & \\
\hline 7. Trust & 3.623 & 0.860 & $-0.547^{* * * *}$ & $-0.316^{* *}$ & 0.008 & 0.071 & 0.017 & $0.161 *$ & & & & & \\
\hline 8. Plant Perf. & 2.690 & 0.580 & 0.092 & 0.027 & 0.040 & 0.003 & -0.020 & 0.001 & $0.013 *$ & & & & \\
\hline 9. Asset specificity & 2.420 & 0.720 & $-0.369 * *$ & $0.239 * *$ & $0.158 *$ & 0.032 & 0.010 & 0.040 & $0.039 * *$ & 0.026 & & & \\
\hline 10. Coercive & 3.590 & 0.450 & $-0.260 *$ & 0.010 & 0.038 & 0.016 & 0.006 & 0.028 & 0.207 * & 0.002 & 0.012 & & \\
\hline 11. Mimetic & 2.240 & 0.410 & $0.212^{\dagger}$ & 0.020 & 0.025 & 0.020 & $0.142 *$ & 0.023 & 0.025 & 0.040 & 0.028 & 0.021 & \\
\hline 12. Normative & 3.010 & 1.450 & $0.499^{* * *}$ & 0.067 & 0.020 & 0.038 & 0.054 & 0.020 & $-0.242^{* *}$ & 0.016 & 0.010 & 0.040 & $0.039^{* *}$ \\
\hline
\end{tabular}

$N=232$. Notes: Significant at: ${ }^{* * *} p<0.001 ;{ }^{* *} p<0.01 ;^{*} p<0.05 ;{ }^{\dagger} p<0.10$ 
Table 3. Regression Results with Third-Country Relocation Intentions as the Dependent Variable

\begin{tabular}{lccccc}
\hline \multicolumn{1}{c}{ Variables } & Model 1 & Model 2 & Model 3 & Model 4 & Model 5 \\
\hline IJV AGE & $-0.103^{* * *}$ & $-0.152^{* * *}$ & $-0.144^{* * *}$ & $-0.120^{* * *}$ & $-0.126^{* * *}$ \\
EMPLOY & 0.004 & 0.022 & 0.013 & 0.014 & 0.019 \\
ASSET & $-0.006^{*}$ & $-0.005^{*}$ & $-0.002^{* *}$ & $-0.004^{*}$ & $-0.078^{* *}$ \\
LIGHT INDUSTRY & -0.018 & -0.024 & -0.031 & -0.033 & -0.026 \\
HEAVY INDUSTRY & -0.285 & -0.301 & -0.205 & -0.203 & -0.105 \\
TRUST & & $-0.523^{* * *}$ & $-0.470^{* * *}$ & $-0.501^{* * *}$ & $-0.450^{* * *}$ \\
PLANT PERFORMANCE & & -0.046 & -0.048 & -0.050 & -0.064 \\
ASSET SPECIFICITY & & $-0.052^{* *}$ & $-0.034^{* *}$ & $-0.058^{*}$ & $-0.055^{*}$ \\
COERCIVE PRESSURE & & $-0.301^{*}$ & $-0.275^{*}$ & $-0.322^{*}$ & $-0.248^{*}$ \\
MIMETIC PRESSURE & & $0.245^{+}$ & $0.218^{+}$ & $0.265^{\dagger}$ & $0.207^{\dagger}$ \\
NORMATIVE PRESSURE & $0.337^{* *}$ & $0.329^{* *}$ & $0.326^{* *}$ & $0.328^{* *}$ \\
TRUST $\times$ PLANT PERFORMANCE & & & $0.205^{*}$ & & $0.207^{*}$ \\
TRUST $\times$ ASSET SPECIFICITY & & & $0.210^{* *}$ & & $0.260^{* *}$ \\
TRUST $\times$ COERCIVE PRESSURE & & & & $0.412^{*}$ & $0.304^{*}$ \\
TRUST $\times$ MIMETIC PRESSURE & & & & $-0.752^{+}$ & $-0.873^{*}$ \\
TRUST $\times$ NORMATIVE PRESSURE & & & & $-0.463^{*}$ & $-0.495^{* *}$ \\
$R^{2}$ & 0.350 & 0.485 & 0.537 & 0.535 & 0.546 \\
$\Delta R^{2}$ & & 0.135 & 0.052 & 0.050 & 0.061 \\
$\Delta F$ value & & $6.901^{* * *}$ & $5.452^{* *}$ & $3.102^{*}$ & $4.105^{* *}$ \\
\hline
\end{tabular}

$N=232$. Notes: Significant at: ${ }^{* * *} p<0.001 ;{ }^{* *} p<0.01 ;{ }^{*} p<0.05 ;{ }^{\dagger} p<0.10$. The changes in $R^{2}$ in models 3 to 5 are compared to the value for $R^{2}$ in model 2 . 
Model 4 reveals the additional variance accounted for by the interactions between institutional theory variables and inter-partner trust is significant $\left(\Delta R^{2}=0.05, p<0.05\right)$. Hypothesis 4 predicts that the negative relationship between inter-partner trust and relocation intention is strengthened when perceived coercive pressure is higher. A significant positive effect is found for the coefficient of the interaction of partner trust and coercive pressure in Model $4(\beta=0.412, p<0.05)$ and full interaction Model 5 ( $\beta=0.304$, $p<0.05)$, giving support to Hypothesis 4 . Figure 5 graphically supports Hypothesis 4 as the magnitude of the slope of relocation intention on partner trust is almost two times higher for low coercive pressure than for high coercive pressure. This result confirms Hypothesis 4, that the negative impact of trust on relocation intention strengthens when perceived coercive pressure is higher.

Hypothesis 5 and Hypothesis 6 predict that the negative relationship between inter-partner trust and relocation intention will be weaker when mimetic and normative pressure are high. The coefficient of the interaction of partner trust with mimetic pressure is marginally significant $(\beta=-0.075, p<0.10)$ but shows stronger effect in the full model $5(\beta=-0.873, p<0.05)$ which supports Hypothesis 5 . Hypothesis 6 is also supported as we find a significant $(\beta=-0.463, p<0.05)$ interaction between partner trust and normative pressure. Also, in the full Model 5 , an effect becomes stronger $(\beta=-0.495$, $p<0.01$ ). To further analyze the implications of the regression results, we plotted the relationship of partner trust and relocation intention over the observed range of partner trust with different levels of mimetic pressure (Figure 6). Also, Figure 7 shows a similar plot with normative pressure. Figure 6 reveals that the magnitude of the slope of relocation intention regressed on partner trust is marginally larger for high memetic pressure as that for low mimetic pressure. Figure 7 shows that the slope for high normative pressure is almost two times as large as that for low normative pressure. Overall, these results imply that the negative trust-relocation relationship weakens at low high levels of two institutional variables (mimetic and normative pressure).

\section{Trust level and plant performance}

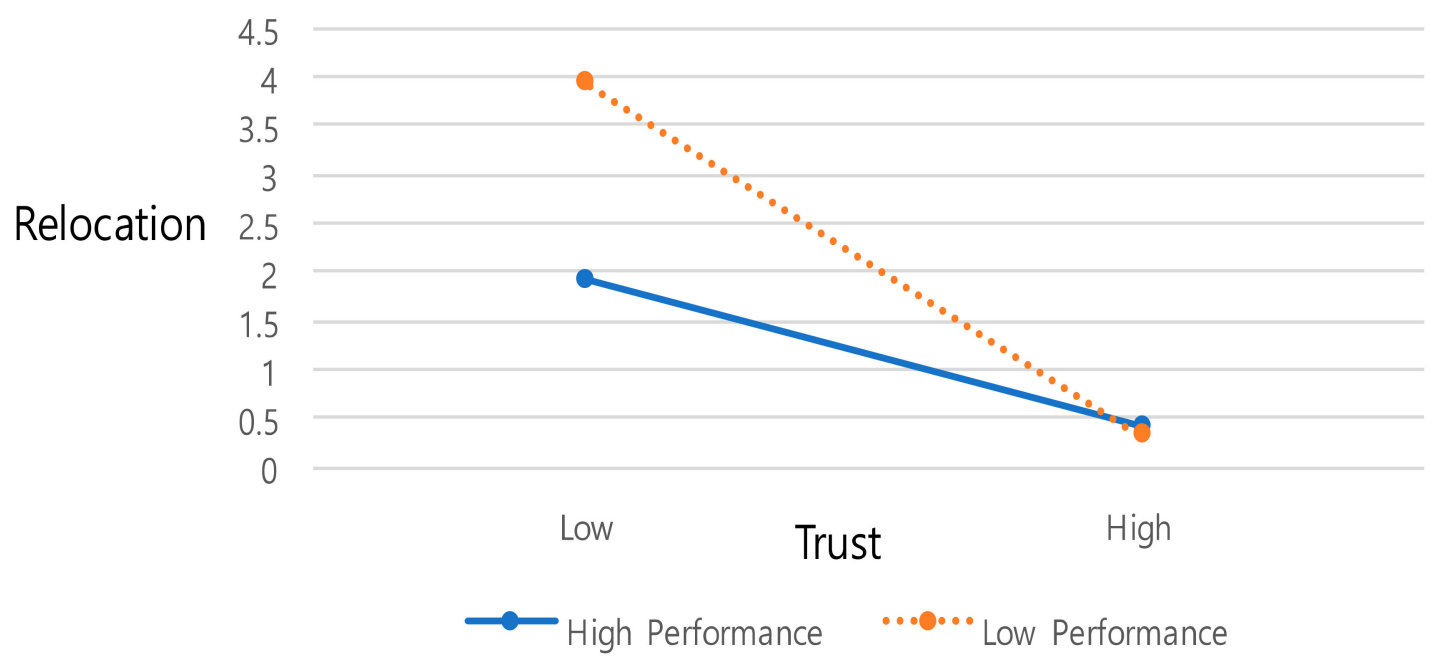

Figure 3. Trust, plant performance, and relocation. 
Trust level and asset specificity

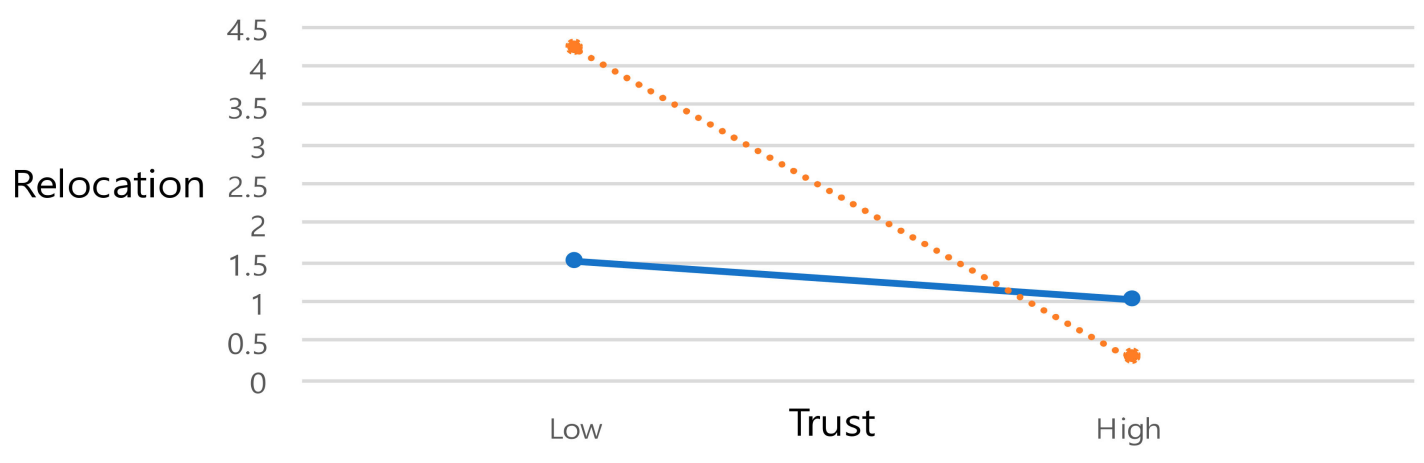

$\longrightarrow$ High asset specificity $\quad \cdots \cdots$ Low asset specificity

Figure 4. Trust, asset specificity, and relocation.

Trust level and coercive pressure

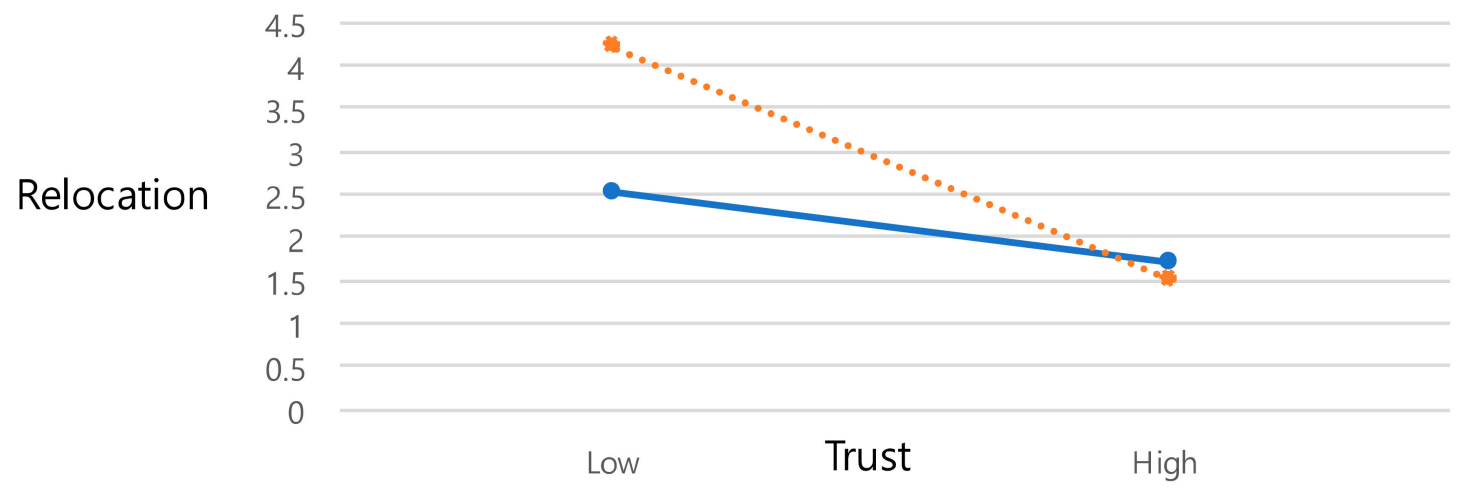

$\longrightarrow$ High coercive pressure $\cdots$ Low coercive pressure

Figure 5. Trust, coercive pressure, and relocation.

Trust level and mimetic pressure

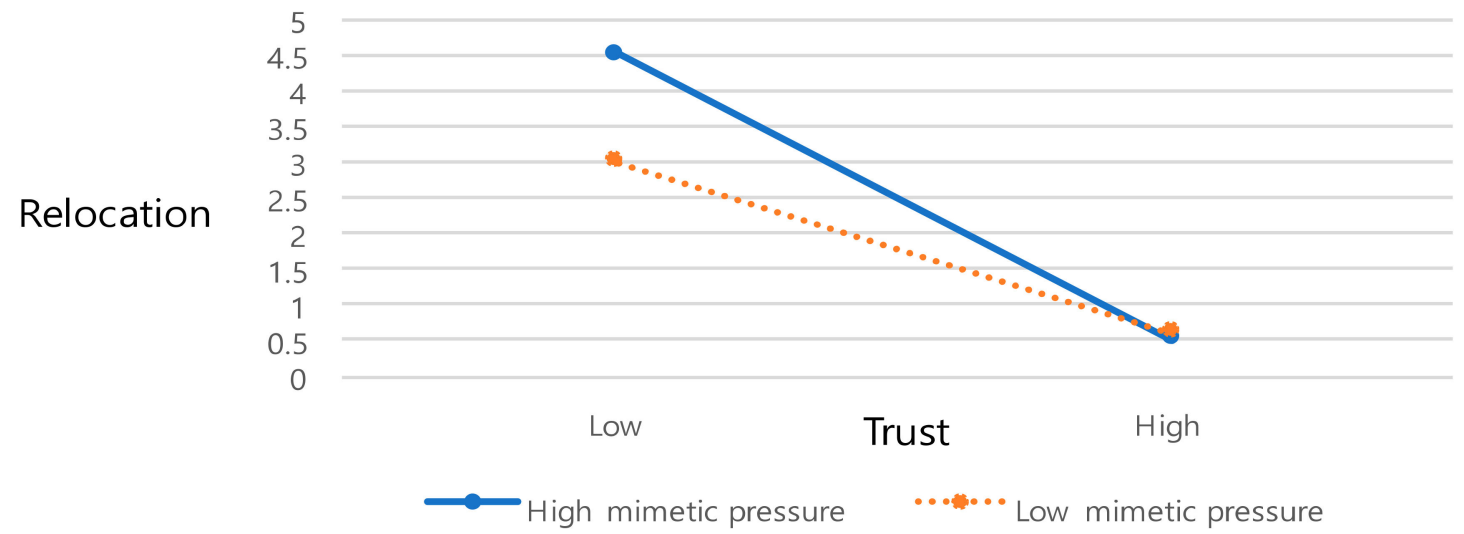

Figure 6. Trust, mimetic pressure, and relocation. 


\section{Trust level and normative pressure}

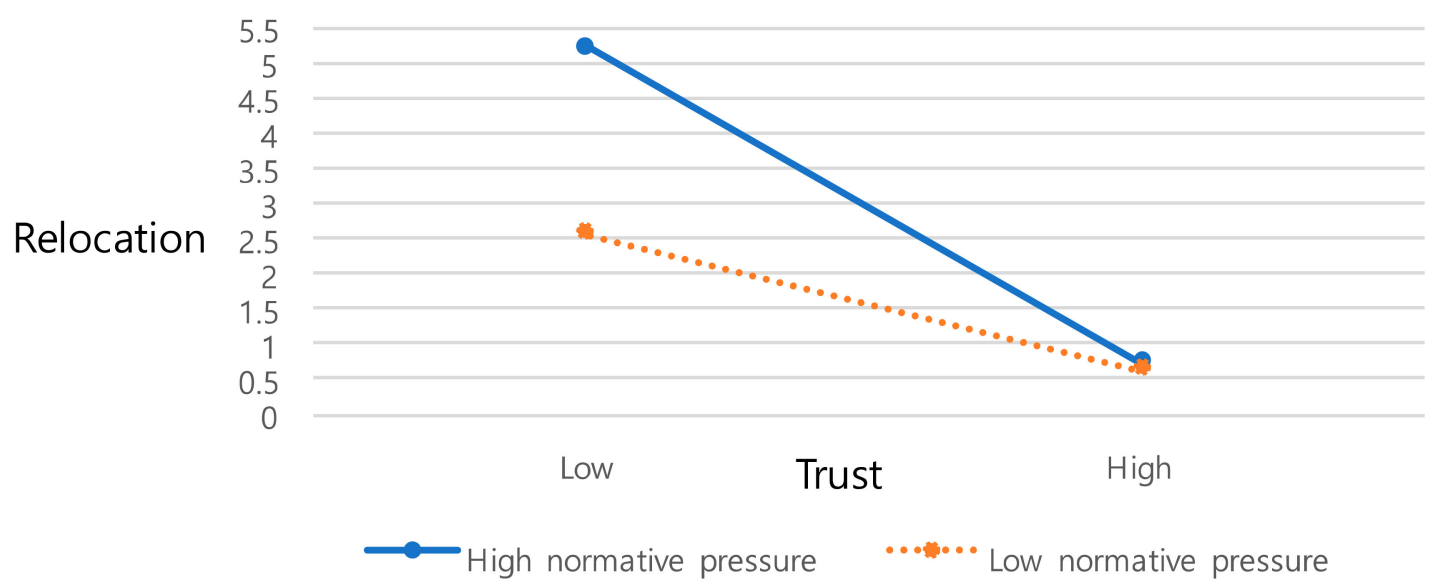

Figure 7. Trust, normative pressure, and relocation.

\section{Case Studies: Trust Management and IJV's Third-Country Relocation}

In addition to previous empirical result, we have included qualitative results of trust management in IJV operations. Previous research shows that trust is the key determinant of the organizational intellectual capital [70]. Human, social, relational, organizational, and innovation dimensions interact and influence trust management. Based on the in-depth interviews with Korean senior managers of IJVs, we categorized how dimensions of human, social, relational, organizational, and innovation interact and influence trust management in IJVs which can be also determinants of third-country relocation intentions.

\subsection{Trust Management and Human Dimension (IJV-A)}

Inter-partner trust relationship has been worsened over the years as Korean senior manager from IJV-A (optical engineering) perceives human resource management (HRM) difficulties. As IJV-A's factory workers' turnover rate is increasing, the factory cannot operate regularly due to shortage of the workers. In the optical engineering industry, it takes five months for manufacturing workers to become skilled workers, but many Chinese factory employees quit in less than a year. It appeared that even one or two US dollars per hour was enough to make workers move from one factory to another. Most of all, IJV-A's Chinese partner did not suggest any solutions for human resource problem that IJV-A is facing. The Korean side perceives that inter-partner trust has been worsened due to the Chinese partner's passive action. In conclusion, IJV-A's Korean management is seriously considering relocating to ASEAN nations where they can find abundant low-cost labor and more cooperating IJV partner.

\subsection{Trust Management and Social Dimension (IJV-B)}

IJV-B, specializing in footwear production, relocated their manufacturing facility to China from Korea in the late 1990s mainly because they found local Chinese partner who have established distribution network within China. Korean manager from IJV-B thought relocation to China would enable them to manufacture their products and supply them to the Chinese market at the same time. However, relocation proved to be a bad choice. IJV-B's Chinese partner's distribution network has been weakened over the years which led to sales decline. From foreigner's perspective, guanxi sustains for long time but nowadays in China, guanxi applies only when companies have cost advantages over competitors. IJV-B's Korean partner questions the ability and the role of Chinese partner as more local Chinese wholesalers cancel the supply contract. As the inter-partner trust and the future of 
IJV-B is uncertain, relocating to Southeast Asia region is an imminent option for their sustainability in operation.

\subsection{Trust Management and Relational Dimension (IJV-C)}

IJV-C's clothes manufacturing does not require high technological skills, so cost management is crucial in their success. At the early stage of their operation, IJV-C were not able to compete with local cost structure. For instance, manufacturing a hoodie cost 15 USD but the local Chinese manufacturer produced a similar product for 7 USD. Later, IJV-C had joint effort with local Chinese partner to find the cost structure in order to narrow the gap against local competitors. Based on close working relationship with local Chinese partner, they applied cost-minimization method called PDCA (plan-do-check-act) which find and eliminate the element of cost escalation factors. Due to PDCA joint effort with Chinese partner, IJV-C was able to lower the cost below the local competitors' level. Korean manager from IJV-C recommend that instead of considering relocation to third-country location, try to solve the current problem with local partner of IJV.

\subsection{Trust Management and Organizational Dimension (IJV-D)}

IJV-D, a plastic product manufacturer, has one value chain system, from designing to manufacturing. IJV-D has been supplying to major multinational manufacturers operating within China and have stable sales and operation. It is mainly because of they have qualified and skillful workforces specially trained for ISO and six sigma standards. IJV-D has confidence in their organizational capability that they will sustain their leading position both in China and in global markets. IJV-D's Korean manager also states that they have strong inter-partner trust and have no intention to relocate their manufacturing facilities to ASEAN nations in the future. Although they are little concerned about rising labor cost in China, they believe that they would not find a local partner with a trust relationship as well as skillful and competent workforces in South East Asia.

\subsection{Trust Management and Innovation Dimension (IJV-E)}

IJV-E is an electrical equipment company, relocated from Korea to China in the late 2000s for low-cost labor force. IJV-E's parent company in Korea had competitive advantage globally and was confident that they would gain a large market share as they gain cost advantage in China. However, as soon as IJV-E launched new product in China, they realized that they were no longer differentiated from local competitors in terms of technological advantage. It appears that local Chinese manufacturers had caught up with IJV-E's technological skills right after new product release. Moreover, IJV-E's Korean partner suspects technological leakage from Chinese side and question the role of local Chinese partner for intellectual property protection. IJV-E's Korean manager seriously considers relocating to third-country location with less advanced technological ability and lower labor cost.

\section{Discussion}

In this research, we found that the trust relationship with a local IJV partner influenced decisions on relocation, drawing from the key theoretical perspectives adopted by firm relocation literature (i.e., behavioral theory and institutional theory). As firm relocation is a new research topic and empirical research is still in the initial stage, we wanted to execute and adopt the partner relationship aspect on relocation decisions in the IJV area. Thus, the results of this research may give new perspectives and insights for academic researchers and practitioners engaged in IJV areas.

The first hypothesis is supported because when a foreign manufacturer has a trust relationship with a local IJV partner, a relocation decision is not likely to take place. The notion of trust in IJVs is confidence in the partner firm's cooperative behavior in an uncertain environment [71]. The outcome of a trust-building relationship is related to risk taking, preserving equity in the IJV, more communication with the partner firm, and inter-firm adaptation. By going through these activities, foreign partner firms are more likely to settle down rather than end the IJV relationship. 
In addition, based on the analytic results, the moderating variables (plant performance and asset specificity) from behavioral theory are supported for moderating the negative relationship between trust and relocation intention. The main focuses of behavioral theory are the internal aspects of the firm that may influence decisions on relocation. In our study, we explored plant performance and asset specificity as internal factors that are significant factors for manufacturing operation. If the IJV is performing well in its current operation, there is no reason for the foreign partner to relocate. Also, when the foreign partner perceives that the IJV has high asset specificity, this becomes an exit barrier for relocation. High asset-specific IJVs may perceive that relocation costs are very substantial, as the foreign partner must reinvest in a third country when they decide to relocate. Therefore, asset specificity is shown to be a strengthening and moderating factor for the negative relationship between trust and relocation intention. IJVs that have long-term, heavy investments in China, have established networks with local firms, and have close relationships with the local Chinese government also have high asset specificity, which can be categorized as factors of sustainable manufacturing operations.

The second moderating variable, institutional theory, is also supported by the data, showing that all coercive, mimetic, and normative pressures from institutions moderate the relationship between trust and relocation intention. As previous research shows, the institutional location theory assumes that economic activity such as a relocation decision is socially and institutionally situated [72,73]. Specifically, society's cultural institutions and value systems shape decision making on relocation. Our results show that high coercive pressure may play a strengthening and moderating role in the negative relationship of trust and relocation intention. On the other hand, perceptions of mimetic and normative pressure have weakening moderating effects on the negative relationship of trust and relocation intention. The results of this study show that an IJV with a foreign partner is sensitive to changes in external environments such as competing foreign manufacturers and a competitive industrial environment. Overall, the relocation decision of a foreign partner in an IJV is not just based on a trust relationship with the local partner firm, but is also an interactive outcome of an ongoing and embedded network with the local government, industry, suppliers, competitors, and other institutions.

\section{Conclusions}

\subsection{Research Implications}

The results of this research shed light on IJV relocation, both theoretically and empirically. It is an emerging research area with room for further research. The empirical results of our research indicate that the IJV relocation phenomenon should be looked at through the lens of partner trust issues. By integrating social factor such as 'trust' into an economically driven firm relocation phenomenon, we can have broad perspective understanding IJV-relocation relationship. Especially, integrating the concept of trust in IJV relocation issue is more significant in Chinese culture which emphasizes personal relationships based on trust rather than formal contracts [9].

We found that the influence of trust can mitigate relocation intention from foreign IJV partner. As a foreign IJV partner relies on a local IJV partner based on trust relationship, a foreign IJV partner less likely to make an ultimate resolution, which is third-country relocation. However, our result shows that at high level of institutional pressures (mimetic and normative), negative trust-relocation relationship is mitigated.

Also, our research framework was based on behavioral and institutional theories that moderate the relationship between trust and relocation intention. IJV relocation is not a simple task for many foreign partners as many IJVs have been operated for more than 10 or 20 years, and can be very asset specific. Having a trust relationship with a local IJV partner may hinder a relocation decision, which can cost a tremendous amount of money. Uncertain business conditions in China do not automatically make relocation an optimal option, and we wanted to identify the inter-partner relationship beforehand.

Our study also used Korean manufacturing IJVs operating in China. Unlike previous relocation studies, our study further explains what factors negatively affect firms' decisions on relocation. In this 
research, Korean partners that are performing well, are highly asset specific and perceive coercive pressure are likely to enforce a negative relationship between partner trust and relocation intention. However, it was found that mimetic pressure and normative pressure play a role in mitigating the negative relationship between inter-partner trust and relocation intention.

In addition, our findings can provide some insights into the black box of managerial relocation decision making. We would argue that firms make relocation decisions based on an inter-partner trust relationship, interacting with the perceived external environment that they face. IJVs constantly explore institutional environments, considering external pressures from local governments, competing firms, and other industry stakeholders. The results confirm the co-evolutionary perspective of the organizations [73] which shows that firms co-evolve based on activities as they are embedded in dynamics within and between them. In similar fashion, Lahiri and Kedia's study [74] showed that firms' decisions on offshore outsourcing are based on learning to remain within their respective environments. In conclusion, our study suggests that foreign IJVs should explore various aspects such as inter-partner relationships and internal and institutional factors before making decisions on IJV relocation.

\subsection{Practical Implications}

In our study, we found that the decision on IJV relocation is a complex one and poses many challenges to decision makers. A relocation decision involves considering various aspects of business environments both locally and internationally. Even if managers are highly interested in relocation, they must consider the inter-partner relationship, local governmental and legal restrictions, and normative pressures coming from the business environment that may make firms less competitive in the foreign manufacturing environment. Most of all, in an uncertain business environment, IJV partners need to explore the optimal structures and processes facilitating trust for mutual benefit. For instance, when IJV partners spot problems and issues surrounding IJV, they should bring the issues to attention immediately [75]. By establishing formal and informal communication channels early on, IJV partners may avoid initial and ongoing problems, thereby sustain IJV cooperation.

Also, foreign IJVs that perceive their assets are highly specific to the local environment are more likely to reconsider or delay plans for relocation. The managers of foreign IJVs must remain alert to changes in the local business environment and should carefully evaluate how a relocation decision affects their sustainability if they move to another country. Also, managers must be always alert to coercive pressures or hidden costs from local government policy, including returning all the tax benefits received from the local government from when operations started.

Also, our study found an important role of trust in IJV. Trust effectively reduces negative signals of partners. IJV partners should facilitate openness in operation by sharing knowledge and increasing more interaction.

For policy makers in other countries, as more foreign manufacturers expect to relocate to adjacent nations, establishing FDI incentive programs can help to host foreign manufacturers. For instance, the South Korean government allocated USD 32 million in 2012 to attract inward FDI from foreign manufacturers operating in China. The same logic applies to other ASEAN nations as the total amount of FDI of Korean firms in five major Southeastern Asian nations (Vietnam, Thailand, Indonesia, Malaysia, and Philippines) surpasses that of China as Korean manufacturing firms witness more wage increases in China [9]. Overall, policy makers need to initiate greater exploration and dialogues with industry so that the negative effects related to inward FDI policy can be minimized.

\subsection{Limitations and Future Research}

This research is limited in that we used a self-reported survey to gather data measuring inter-partner trust and the relocation decisions of only South Korean IJVs operating in China, which reduces the generalizability of the results. Future studies may include multiple countries, industries, and firm characteristics, which may have different effects on relocation decisions. 
In addition, this study is cross-sectional. We suggest further longitudinal analysis that tracks actual relocation outcomes rather than intentions to relocate. As the IJV relocation phenomenon is a relatively new area, a promising research agenda would be to explore the performance of foreign manufacturers that have left China to seek lower wages and better manufacturing environments. Specifically, it will be beneficial for the field of relocation to explore how manufacturing firms take action after relocation decisions are made. For instance, foreign manufacturing firms need to communicate and negotiate with local governments before relocation takes place. As our research shows, there are several exit barriers for relocation, such as coercive pressures from the local government. For foreign IJV partners that decided to exit, these firms should prepare for divestiture in order to avoid conflicts with local IJV partners. Also, future research can be conducted by evaluating relocation performance and benefits or downsides of relocation decisions. Regarding the inter-partner trust issue, we suggest that qualitative insights would be helpful to unfold the whole process of the IJV inter-partner relationship.

In addition, due to the sensitivity of the topic (IJV relocation), we were only able to collect surveys from foreign IJV partners not including local IJV partners. By including samples from local partners, future research can explore IJV dissolution issue rather than the topic of third-country relocation.

As relocation research may draw more attention from the policy makers of ASEAN nations who want to promote inward FDI, future studies should focus more on how industrial policy affects firms' decisions on relocation. Such studies can contribute to favorable and sustainable incentive programs for inward FDI specialized in the relocation of foreign manufacturers operating in China.

Finally, we hope that this study will open more research and discussions on relocation phenomena among scholars in different disciplines. With future studies, scholars can help international executives become more aware of their strategic options for allocating international resources depending on how the executives perceive dynamic, changing business environments. Also, more researchers should explore fundamental questions with respect to the trust relationship in IJVs and how it contributes to operation sustainability.

Author Contributions: Y.-S.H. designed the study and collected data. K.K. analyzed and interpreted data. Both authors equally contributed writing the manuscript.

Funding: This research has received no external funding.

Conflicts of Interest: The authors declare no conflict of interest.

\section{References}

1. Chu, K. China loses edge on labor costs. Wall Street Journal, 3 December 2015.

2. MIT Forum. U.S. Re-Shoring: A Turning Point; Massachusetts Institute of Technology: Cambridge, MA, USA, 2012.

3. Werner, S.; Brouthers, L.E.; Brouthers, K.D. International risk and perceived environmental uncertainty: The dimensionality and internal consistency of Miller's measure. J. Int. Bus. Stud. 1996, 27, 571-587. [CrossRef]

4. Ming, B. Migratory manufacturers: Foreign enterprise relocate to Southeast Asia. China Today, February 2013.

5. Einhorn, B. China's manufacturers seek ways to cut costs. Business Week, 20 June 2013.

6. Fratocchi, L.; Ancarani, A.; Barbieri, P.; Di Mauro, C.; Nassimbeni, G.; Sartor, M.; Vignoli, M.; Zanoni, A. Motivations of manufacturing reshoring: An interpretative framework. Int. J. Phys. Distrib. Logist. 2016, 46, 98-127. [CrossRef]

7. Foerstl, K.; Kirchoff, J.F.; Bals, L. Reshoring and insourcing: Drivers and future research directions. Int. J. Phys. Distrib. Logist. 2016, 46, 492-515. [CrossRef]

8. Gray, J.V.; Skowronski, K.; Esenduran, G.; Rungtusanatham, M.J. The reshoring phenomenon: What supply chain academics ought to know and should do. J. Supply Chain Manag. 2013, 49, 27-33. [CrossRef]

9. Kim, S. Leaving or remaining: Dilemmas of Korean firms in China. Segye Finance, 26 August 2012.

10. Ng, P.A.-K.; Lau, C.-M.; Nyaw, M.-K. The effect of trust on international joint venture performance in China. J. Int. Manag. 2007, 13, 430-448. [CrossRef]

11. Boersma, M.F.; Buckley, P.J.; Ghauri, P.N. Trust in international joint venture relationships. J. Bus. Res. 2003, 56, 1031-1042. [CrossRef] 
12. Krishnan, R.; Martin, X.; Noorderhaven, N.G. When does trust matter to alliance performance? Acad. Manag. J. 2006, 49, 894-917. [CrossRef]

13. Peng, M.; Wang, D.; Jiang, Y. An institution-based view of international business strategy: A focus on emerging economies. J. Int. Bus. Stud. 2008, 39, 920-936. [CrossRef]

14. Dunning, J.H.; Lundan, S.M. Institutions and the OLI paradigm of multinational enterprise. Asia Pac. J. Manag. 2008, 25, 573-593. [CrossRef]

15. Gammeltoft, P.; Barnard, H.; Madhok, A. Emerging multinationals, emerging theory: Macro- and micro-level perspectives. J. Int. Manag. 2010, 16, 95-101. [CrossRef]

16. Cheng, H.L.; Yu, C.M. Institutional pressures and initiation of internationalization: Evidence from Taiwanese small and medium sized enterprises. Int. Bus. Rev. 2008, 17, 331-348. [CrossRef]

17. Hessels, J.; Terjesen, S. Resource dependency and institutional theory perspectives on direct and indirect export choices. Small Bus. Econ. 2010, 34, 203-220. [CrossRef]

18. Korea Trade-Investment Promotion Agency (KOTRA). Directory of Korean Firms Entered Overseas: China; KOTRA: Seoul, Korea, 2016.

19. Hayter, R. The Dynamics of Industrial Location. The Factory: The Firm and the Production System; Wiley: New York, NY, USA, 1997.

20. Brouwer, A.; Mariotti, I.; van Ommeren, J.N. The firm relocation decision: An empirical investigation. Ann. Reg. Sci. 2004, 38, 335-347. [CrossRef]

21. Dunning, J.H. The location of foreign direct investment activity, country characteristics and experience effects. J. Int. Manag. 1980, 11, 9-22.

22. Vernon, R. International investment and international trade in the product cycle. Q. J. Econ. 1966, 80, $190-207$. [CrossRef]

23. Di Mauro, C.; Fratocchi, L.; Orzes, G.; Sartor, M. Offshoring and backshoring: A multiple case study analysis. J. Purch. Supply Manag. 2018, 24, 108-134. [CrossRef]

24. Williamson, O. Outsourcing: Transaction cost economics and supply chain management. J. Supply Chain Manag. 2008, 44, 5-16. [CrossRef]

25. Ministry of Economy, Trade and Industry. White Paper on Japanese Manufacturing Sector; Ministry of Economy, Trade and Industry: Tokyo, Japan, 2004.

26. Handley, S.M.; Benton, W.C. The influence of task and location-specific complexity on the control and coordination costs in global outsourcing relationships. J. Oper. Manag. 2013, 31, 109-128. [CrossRef]

27. Ancarani, A.; Di Mauro, C.; Fratocchi, L.; Orzes, G.; Sartor, M. Prior to reshoring: A duration analysis of foreign manufacturing ventures. Int. J. Prod. Econ. 2015, 169, 141-155. [CrossRef]

28. Davidson, W.H. The location of foreign direct investment activity: Country characteristics and experience effects. J. Int. Bus. Stud. 1980, 11, 9-22. [CrossRef]

29. Manning, S. Mitigate, tolerate or relocate? Offshoring challenges, strategic imperatives and resource constraints. J. World Bus. 2014, 49, 522-535. [CrossRef]

30. Milliken, F.J. Three types of perceived uncertainty about the environment: State, effect, and response uncertainty. Acad. Manag. Rev. 1987, 12, 133-143. [CrossRef]

31. Tate, W.L. Offshoring and reshoring: U.S. insights and research challenges. J. Purch. Supply Manag. 2014, 20, 66-68. [CrossRef]

32. Rotter, J.B. Generalized expectancies of interpersonal trust. Am. Psychol. 1971, 26, 443-452. [CrossRef]

33. Parkhe, A. Messy research, methodological predisposition, and theory development in international joint ventures. Acad. Manag. Rev. 1993, 18, 227-268.

34. Zaheer, S.; Zaheer, A. Trust across borders. J. Int. Bus. Stud. 2006, 37, 21-29. [CrossRef]

35. Cyert, R.M.; March, J.G. A Behavioral Theory of the Firm; Blackwell: Malden, MA, USA, 1992.

36. Audia, P.G.; Greve, H.R. Less likely to fail: Low performance, firm size, and factory expansion in the shipbuilding industry. Manag. Sci. 2006, 52, 83-94. [CrossRef]

37. Scott, R. Institutions and Organizations; Sage: Thousand Oaks, CA, USA, 2001.

38. North, D.C. Institutions, Institutional Change, and Economic Performance; Harvard University Press: Cambridge, MA, USA, 1990.

39. DiMaggio, P.J.; Powell, W.W. The iron cage revisited: Institutional isomorphism and collective rationality in organization fields. Am. Sociol. Rev. 1983, 48, 147-160. [CrossRef] 
40. Yan, A.; Gray, B. Bargaining power, management control, and performance in United States-China joint ventures: A comparative case study. Acad. Manag. J. 1994, 37, 1478-1517.

41. Madhok, A.; Tallman, S.B. Resources, transactions and rents: Managing value through interfirm collaborative relationships. Organ. Sci. 1998, 9, 326-339. [CrossRef]

42. Tsai, W.; Ghoshal, S. Social capital and value creation: The role of intrafirm networks. Acad. Manag. J. 1998, 41, 1478-1517.

43. Baird, I.S.; Lyles, M.A.; Ji, S.; Wharton, R. Joint Venture Success: A Sino-U.S. Perspective. Int. Stud. Manag. Org. 1990, 20, 125-134. [CrossRef]

44. Li, J.J.; Zhou, K.Z.; Lam, S.S.K.; Tse, D.K. Active trust development of local senior managers in international subsidiaries. J. Bus. Res. 2006, 59, 73-80. [CrossRef]

45. Ariño, A.; de la Torre, J. Learning from failure: Towards an evolutionary model of collaborative ventures. Organ. Sci. 1998, 9, 306-325. [CrossRef]

46. Prahalad, C.K.; Hamel, G. The core competence of the corporation. Harv. Bus. Rev. 1990, 68, 79-91.

47. Real, J.C.; Leal, A.; Roldán, J.L. Information technology as a determinant of organizational learning and technological distinctive competencies. Ind. Mark. Manag. 2006, 35, 505-521. [CrossRef]

48. Steensma, H.K. Acquiring technological competencies through inter-organizational collaboration: An organizational learning perspective. J. Eng. Technol. Manag. 1996, 12, 267-286. [CrossRef]

49. Sidhu, J.S.; Nijssen, E.J.; Commandeur, H.R. Business domain definition practice: Does it affect organizational performance? Long Range Plan. 2000, 33, 376-401. [CrossRef]

50. Baum, J.A.C.; Rowley, T.J.; Shipilov, A.V.; Chuang, Y.-T. Dancing with strangers: Aspiration performance and the search for underwriting syndicate partners. Adm. Sci. Q. 2005, 50, 536-575. [CrossRef]

51. Lui, S.S.; Wong, Y.-Y.; Liu, W. Asset specificity roles in interfirm cooperation: Reducing behavior or increasing cooperative behavior? J. Bus. Res. 2009, 62, 1214-1219. [CrossRef]

52. Espino-Rodríguez, T.F.; Lai, P.C. Activity outsourcing and competitive strategy in the hotel industry. The moderator role of asset specificity. Int. J. Hosp. Manag. 2014, 42, 9-19. [CrossRef]

53. Puck, J.F.; Holtbrügge, D.; Mohr, A.T. Beyond entry mode choice: Explaining the conversion of joint ventures into wholly-owned subsidiaries in the People's Republic of China. J. Int. Bus. Stud. 2009, 40, 388-404. [CrossRef]

54. Mesquita, L.F.; Brush, T.H. Untangling safeguard and production coordination effects in long-term buyer-supplier relationships. Acad. Manag. J. 2008, 51, 785-807.

55. Delios, A.; Gaur, A.S.; Makino, S. The timing of international expansion: Information, rivalry and imitation among Japanese firms, 1980-2002. J. Manag. Stud. 2007, 45, 169-195. [CrossRef]

56. Li, J.; Yang, J.; Yue, D. Identity, community, and audience: How wholly owned foreign subsidiaries gain legitimacy in China. Acad. Manag. J. 2007, 50, 175-190. [CrossRef]

57. Salomon, R.; Wu, Z. Institutional distance and local isomorphism strategy. J. Int. Bus. Stud. 2012, 43, 343-367. [CrossRef]

58. Yiu, D.; Makino, S. The Choice between Joint Venture and Wholly Owned Subsidiary: An Institutional Perspective. Organ. Sci. 2002, 13, 667-683. [CrossRef]

59. Podsakoff, P.M.; Organ, D.W. Self-reports in organizational research: Problems and prospects. J. Manag. 1986, 12, 531-544. [CrossRef]

60. Sharif, N.; Huang, C. Innovation strategy, firm survival and relocation: The case of Hong Kong owned manufacturing in Guangdong Province, China. Res. Policy 2012, 41, 69-78. [CrossRef]

61. Morgan, R.M.; Hunt, S.D. The commitment-trust theory of relationship marketing. J. Mark. 1994, 58, $20-38$. [CrossRef]

62. Bhatnagar, R.; Sohal, A. Supply chain competitiveness: Measuring the impact of location factors, uncertainty and manufacturing practices. Technovation 2005, 25, 443-456. [CrossRef]

63. Brouthers, K.D. Institutional, cultural and transaction cost influences on entry mode choice and performance. J. Int. Bus. Stud. 2002, 33, 203-221. [CrossRef]

64. Cui, L.; Jiang, F. State ownership effect on firms' FDI ownership decisions under institutional pressure: A study of Chinese outward-investing firms. J. Int. Bus. Stud. 2012, 43, 264-284. [CrossRef]

65. Saraf, N.; Liang, H.; Xue, Y.; Hu, Q. How does organizational absorptive capacity matter in the assimilation of enterprise information systems? Inf. Syst. J. 2012, 23, 245-267. [CrossRef] 
66. Granovetter, M. Economic institutions as social constructions: A framework for analysis. Acta Sociol. 1992, 35, 3-11. [CrossRef]

67. Mason, C.M. Intra-urban plant relocation: A case study of Greater Manchester. Reg. Stud. 1980, 14, $267-283$. [CrossRef]

68. Dickson, P.H.; Weaver, K.M. Environmental determinants and individual level moderators of alliance use. Acad. Manag. J. 1997, 40, 404-425.

69. Hair, J.F., Jr.; Babin, B.; Money, A.H.; Samuel, P. Essentials of Business Research Methods; Wiley: New York, NY, USA, 2003.

70. Kożuch, B.; Lenart-Gansiniec, R. Trust and Knowledge Sharing. In Intuition, Trust, and Analytics; Liebowitz, L., Paliszkiewicz, J., Gołuchowski, J., Eds.; CRC Press, Taylor \& Francis Group, Auerbach Publications: Boca Raton, FL, USA, 2018.

71. Das, T.K.; Teng, B.-S. Between trust and control: Developing confidence in partner cooperation in alliances. Acad. Manag. Rev. 1998, 23, 491-512. [CrossRef]

72. Amin, A. An institutionalist perspective on regional economic development. Int. J. Urban Reg. 1999, 23, 365-378. [CrossRef]

73. Volberda, H.W.; Lewin, A.Y. Co-evolutionary dynamics within and between firms: From evolution to co-evolution. J. Manag. Stud. 2003, 40, 2111-2136. [CrossRef]

74. Lahiri, S.; Kedia, B.L. Co-evolution of institutional and organizational factors in explaining offshore oursourcing. Int. Bus. Rev. 2011, 20, 252-263. [CrossRef]

75. Lewis, J.D. Using alliances to build market power. Plan. Rev. 1990, 18, 4-48. [CrossRef]

(C) 2018 by the authors. Licensee MDPI, Basel, Switzerland. This article is an open access article distributed under the terms and conditions of the Creative Commons Attribution (CC BY) license (http:/ / creativecommons.org/licenses/by/4.0/). 